\title{
Violence against women: Can "jealousy" mitigate the significance of violence?
}

\author{
Violência contra a mulher: o "ciúme" pode \\ atenuar o significado da violência?
}

\author{
Nazaré COSTA ${ }^{1}$ \\ Holga GOMES ${ }^{2}$ \\ Thaís ALMEIDA ${ }^{3}$ \\ Renata Silva PINHEIRO 4 \\ Calíope ALMEIDA ${ }^{5}$ \\ Ludmilla GONDIM ${ }^{6}$ \\ Mayra SILVA ${ }^{5}$ \\ Rayane Sobral CAMPOS $^{5}$ \\ Stephanie Matos SILVA $^{5}$ \\ Valentina LIMA $^{5}$
}

\begin{abstract}
Beliefs about love and jealousy can be variables that influence violence against women. The aim of our reproduction of a United States study was to compare our data with those of the original study regarding the acceptance of violence related to jealousy. A total of 264 college students participated in the study. They heard and assessed two audio recordings ("jealousy" and "no jealousy"), but half heard situations in which the husband beat his wife and half situations in which the husband does not beat his wife. After each audio recording, participants answered six questions, among them: "how much the husband loves his wife" and "how long would the relationship last". It was observed that, aggression, in the case of "no jealousy", showed to have a negative meaning both in the United States study and in the present study, which was not observed in the case of "jealousy". It may be concluded that violence against women is a cultural practice in Brazil and that social rules regarding male honor, female submission and jealousy exert influence on this practice.
\end{abstract}

Keywords: Jealousy; Love; Violence against women - Brazil.

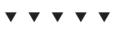

1 Universidade Federal do Maranhão, Departamento de Psicologia, Programa de Pós-Graduação em Psicologia. Av. dos Portugueses, s/n., 65085-580, São Luís, MA, Brasil. Correspondência para/Correspondence to: N. COSTA. E-mail: <naza.pc@gmail.com>.

2 Universidade Federal do Maranhão, Curso de Psicologia, Departamento de Psicologia. São Luís, MA, Brasil.

${ }^{3}$ Instituto de Terapia por Contingências de Reforçamento, Curso de Especialização em Terapia Comportamental. Campinas, SP, Brasil.

${ }^{4}$ Universidade Federal do Pará, Núcleo de Teoria e Pesquisa do Comportamento, Programa de Pós-Graduação em Teoria e Pesquisa do Comportamento. Belém, PA, Brasil.

5 Universidade Federal do Maranhão, Curso de Psicologia, Grupo de Pesquisa sobre Violência Contra a Mulher e Ciúme. São Luís, MA, Brasil.

${ }^{6}$ Psicóloga. Salvador, BA, Brasil.

Support: Fundação do Amparo à Pesquisa e Desenvolvimento Cientifico do Maranhão (Universal-00358/12).

The study is the result of Grupo de Pesquisa sobre Violência Contra a Mulher e Ciúme of Universidade Federal do Maranhão. 


\section{Resumo}

Crenças sobre amor e ciúme podem constituir-se em variáveis que influenciam a violência contra a mulher. Esta replicação de um estudo norte-americano buscou, sobretudo, comparar os dados encontrados com os do estudo original quanto à aceitação da violência relacionada ao ciúme. Participaram 264 universitários. Todos ouviram e avaliaram dois áudios ("ciúme" e "não ciúme"), porém, metade ouviu que o marido bate na esposa e metade que ele não bate. Após cada áudio, os participantes avaliaram seis questões, dentre elas, o quanto o marido amava a esposa e quanto duraria a relação. Observou-se que a agressão, na condição "não ciúme", teve um significado acentuadamente negativo tanto no estudo norte-americano quanto no atual, o que não foi observado na condição "ciúme". Concluiu-se que a violência contra a mulher é uma prática cultural no Brasil e que regras sociais sobre honra masculina, submissão feminina e ciúme exercem influência sobre essa prática.

Palavras-chave: Amor; Ciúmes; Violência contra mulher - Brasil.

In Brazil, women account for approximately $8 \%$ of all homicides recorded (Waiselfisz, 2014). Last year, the 2014 Map of Violence showed that more than 4,500 women were homicide victims. According to data obtained in the 2012 Map of Violence, which analyzed hospital records of violence from the Unified Health System (SUS, Sistema Único de Saúde), 70,720 women had been victims of physical violence in 2011 . Of these, $71.8 \%$ of aggressions occurred at the victim's home. In almost half the cases, the aggressor was the partner or former partner of the victim, characterizing domestic violence or violence involving intimate partners, which has greatly impacted women's homicide rates. Of 95 countries, Brazil occupies the $7^{\text {th }}$ place in the ranking of femicides.

Despite the high figures available, it is believed that domestic violence is an even greater problem when we consider the following: (a) a significant number of cases are not reported; (b) the difficulty in recognizing a situation as being violent; (c) a certain level of social acceptance or justification for episodes of violence in some cases (Baptista, 2012; Gomes \& Costa, 2014; Puente \& Cohen, 2003).

Regarding the non-identification of some violent cases, as it involves several different aspects (physical, sexual, economic, psychological and social), violence against women is a complex phenomenon, which often occurs covertly, making it difficult even for the woman to identify it, as in case of psychological violence that is rarely identified as such until it is combined with physical violence (Baptista, 2012).
Moreover, each person's interpretation of events is behavior and thus it depends on how we relate to the environment. We respond differently to the world we live in depending on one's past experience with the environment (Skinner, 1974/ 1995). Therefore, some factors that are associated with cultural and ontogenetic issues present in the life of the woman makes it difficult for her to interpret the situation as being violent, such as: history of domestic violence in her family, belief in romantic love, strong belief in the family unit, and the stereotyped role of women (Baptista, 2012).

Considering the social acceptance of some episodes of violence, Puente and Cohen (2003) warn that "beliefs about jealousy, love and violence can be combined to create a dangerous syllogism in which domestic violence is at least relatively acceptable" (p.449). We must therefore be aware of the great influence of the socio-cultural context in the spread of aggressive behavior, for the social environment is often responsible for aggressive responses between intimate partners and the perpetuation of women in cycles of violence. "The social group acts sharply, since birth, making boys and girls assimilate appropriate behavioral patterns for each of them" (Gomes \& Costa, 2014, p.90). In this sense, rules related to the submissive role of women in committed relationships are commonly, directly or indirectly, instilled since childhood.

Violence against women persists for several reasons: social rules related to the women's traditional role, the sacredness of the family and its ideal model, financial dependence on the partner, lack of another place to live or shelter after the 
woman files a complaint, reinforcement of men when acting aggressively, among others (Sinclair, 1985/2010).

Among the commonly given reasons for violence against women is "jealousy" of the partner or ex-partner (Baptista, 2012; Blay, 2003). However, according to Behavior Analysis, this would be considered a poor explanation for understanding the phenomenon. Jealousy is a behavior that includes reflex and operant components, elicited and/or controlled by a situation of competition (environmental event), and therefore it cannot be the "cause" of violence, since one behavior cannot explain another behavior (Costa, 2009).

In this sense, based on interviews with 10 women victims of violence, Lacerda and Costa (2013) proposed that violent responses in such cases would be a topography of emotional jealous behavior (thus, the term "jealousy" appears in quotation marks, considering the proposition of Costa, 2009) because the incidence of violent responses, in these situations, would the same as "jealousy": attenuation of the competitive situation with a rival (negative reinforcement) and/or attention of the partner (positive reinforcement).

The relationship between emotional jealous behavior and violence was previously discussed by Puente and Cohen (2003), as discussed in the present article. The researchers conducted three studies and one of them was to analyze the hypothesis that people can mitigate the meaning of violence when it occurs in a context of "jealousy" associated with love. In their study, conducted with 49 freshman Psychology students, the authors found that the initial hypothesis was confirmed. When "jealousy" was presupposed, people accepted, albeit covertly, the aggressive response of a man against his wife when it was "justified" by emotional jealous behavior.

Schraiber et al. (2007) state that violence suffered by women is often serious and repetitive, with consequences that affect the woman's physical, psychological and reproductive health, which may persist even after the cessation of violence. For this reason, studies are an important instrument to deepen our understanding on the problem of violence against women and thus contribute to its reduction.

In general, the present study consists of the reproduction of the three surveys conducted by Puente and Cohen (2003), which is described in the method. Thus, the aims of the present research, as previously mentioned, are the same as those of the authors, but we have added two more goals: to determine whether we would find similar results as those in the North-American study regarding the acceptance of violence related to emotional jealous behavior; and identify whether there are differences in the answers considering the participant's gender.

\section{Method}

\section{Participants}

The convenience sample was composed of 264 college students (half male and half female) from the Human Sciences Department at a public university. The total number of participants was determined by extracting $10 \%$ of the population of active students at the time of data collection $(n=2,648)$.

To be included in the survey, the participant had to be 18 years old or older and regularly enrolled in any of the courses at the department. Exclusion criteria were the presence of some level of hearing impairment that prevented the understanding of audio recording and if they had participated in the recording used in the research.

\section{Instruments}

Data collection was carried out on the premises of the Human Sciences Department with a lower incidence of intervening variables, such as people transiting or loud noise, or as agreed between the participant and the research assistant.

Eight Ipod Shuffle devices were used to playback the audio recording during data collection. To record the responses of participants, a two-part questionnaire was applied: (a) questions requesting 
information about the participant (age, sex, marital status and undergraduate course); (b) twenty-two items grouped into three categories, and three open-ended questions. In the first four questions, participants answered a 5-point Likert scale items (nothing, little, moderately, a lot, completely/forever) and questions 5 and 6 had two options. The questions assessed were: (1) regarding the husband: he loves his wife, wants to take care of his wife, wants to be with his wife, desires his wife and cares about her; (2) the husband's reaction: understandable, justifiable, acceptable and good; (3) the husband is: insecure, immature, foolish, stupid, selfish, petty, vindictive, sadistic, self-centered, a bad husband, a bad father, a bad man; (4) and how long would the marriage last. The two options for questions 5 from which participants had to choose were: staying or leaving the husband if I were his wife; for question 6 , if they were the best friend of the wife. It is noteworthy that in question 1 of the original study, in addition to the items mentioned above, there was the following additional question: "How much does the husband respect his wife", but it was not included in the questionnaire in the present study. As the present questionnaire is a reproduction, the questions of the instrument were deleted or altered, and the measures used to compare the data (described below) were the same as those of the original ( $F$ and mean values).

\section{Procedures}

Before starting the collection, we recorded the audio that would be used for the study. For this purpose, one of the research students contacted students where the research was being conducted, seeking those with good diction and oral expression. The audio recordings were evaluated by the research group and new recordings took place until they presented the desired intonation for each condition and situation. The final version of the audio recording was recorded by two students who agreed voluntarily.

The students were approached, individually

$\mathbf{5 2 8}$ or in groups of up to 10 people, by the research students who identified themselves as students regularly enrolled in the course of Psychology and members of the research team. The purpose of the research was explained and the participant would individually listen to audio recordings on the iPod using a headset to assess excerpts from an interview regarding a fictional study that dealt with romantic relationships. When the participants were approached in groups, they were given instructions not to interact or comment the research when filling out the questionnaires.

Those who were interested and agreed to participate signed a consent form. All participants heard and assessed two audio recordings ("jealousy" and "no jealousy"), but half heard that the husband beat his wife (aggressive situation) and half that he did not (non-aggressive situation).

After that, it was explained to the participants how the data collection worked: they would hear two audio recordings that reported the last fight experienced by a couple, as described below:

1) "Jealousy" (Flirting at the party): a man describes a situation at a party and realizes that his wife was flirting with another man. The man makes it clear that he and his wife had not consumed any alcohol. He also reports that he attempted to call his wife's attention saying that he suspected she did not want to leave because he wanted to flirt with the other man, but finally he convinces her to leave the party. However, they began to argue as soon as they got home. At the height of the argument, he: (a) hits his wife "so she has something to think about" - aggressive situation; or (b) left and went to a friend's house to calm down playing billiards non-aggressive situation. The interviewer then asks him if he usually reacted that way. In both situations the husband replies "yes" and that he acted that way because he was "jealous".

2) "No jealousy" (business lunch): a man describes a time when he had lunch with some business clients and tried to pay the bill with his credit card, but he was told by the waiter that his card had exceeded the credit limit. The man reported that he felt embarrassed in front of his clients because he was put in a bad situation. He 
reported being very angry because he had already asked his wife not use the credit card, an agreement that she had obviously decided to completely ignore. He goes home to complain to his wife about the bad situation in front of his clients she had put him in. When he got home, he found his wife watching TV, which probably had also been purchased with the credit card, and wearing clothes and makeup she had purchased with the credit card. They started arguing and at one point she said, "Well, the credit card is also mine and I can use it when I wish to". At the height of the argument, he: (a) beats his wife "seeking to defend his point of view" aggressive situation; or (b) goes out for a walk to cool off - non-aggressive situation. Finally, the interviewer asks him if he usually reacted that way, and for both situations he answers "yes". In the audio recording of aggression, he claims to have beaten her once before because she had broken an agreement they had made. In the audio recording of non-aggression he says that when he feels very angry he usually goes for a walk.

After listening to each audio recording, the participants were asked to rate the different items in the previously mentioned survey questionnaire. At the end of each session, the research student thanked the participants for their collaboration and data collection ended. Each participant took an average of 15 minutes to listen to the audio and answer the questionnaire.

We compared each of the items between the situations where the husband responds aggressively to his wife and those in which he did not in the case of "jealousy" (Flirting at a party) and "no jealousy" (business lunch). These audio recordings were considered as independent variables for the data analysis. We also analyzed the answers found in each item in accordance with the participant's gender to identify whether there are differences in responses based on this variable.

The quantitative analysis was performed using the Statistical Package for Social Sciences (SPSS) version 15.0. First, the means and deviation for each of the questions answered by the participants were obtained, which were classified as dependent variables and denominated as factors. These factors were formed by grouping the items that composed the six questions and that do not correspond exactly with the titles used in the questionnaire, nor the sequence of items. The factors, according to the translation of the titles of the original questionnaire, were as follows: 1) romantic love: love, desire to take care, want to be together and desire the wife; 2) companionate love: concern for wife; 3) prognosis/advice: marriage duration and counseling (if one were to be the wife's best friend, would one give advice to leave or stay with her husband); 4) understanding: understandable, justifiable, acceptable and good; 5) morally bad: selfish, petty, vindictive, sadistic, self-centered, a bad husband, and bad father; 6) characteristics of husband: insecure, immature, foolish and stupid. In the original study, the question about the marriage duration and the two questions about advice were combined and grouped into the factor "prognosis". However, in our the reproduction, the question about the marriage duration was answered on the 5-point Likert scale and the two questions about counseling (values 1 and 2) were analyzed separately due to impossibility of grouping them in the SPSS because they have different formats.

Considering that the participants answered on a five-point scale, for the data analysis of the factors romantic love, companionate love and understanding, the higher values indicated the presence of more love (romantic and companionate love) of the husband toward his wife, as well as his reaction being more understanding. As for the morally bad factor, lower values indicated negative moral qualities. The characteristics of the husband factor was excluded from the analysis because it did not appear in the results and discussions of the study used as reference.

After grouping the data, multifactorial correlation analyses (Manova) was performed, separating them into two separate groups considering the case of "jealousy" and "no jealousy". In the data analyses they were not separated into factors. To verify the correlation between the items of each factor, Cronbach's alpha 
was calculated for each factor that had more than one item. The $t$ - test was performed for gender and aggressive and non-aggressive situations to identify whether there was a significant difference between the participants' responses correlating these two variables.

The study was approved by the Ethics Committee under protocol $n^{\circ}$ 23115016210/2011-99 on December 15, 2011.

\section{Results and Discussion}

Considering that the study sought to test the hypothesis that violence would have a negative meaning if it occurred in the context of no "jealousy" and would not have this meaning if it occurred in the context of "jealousy", comparing the results obtained with the study of Puente and Cohen (2003) and verifying the differences in responses according to gender, we will only describe the results that answering that hypothesis.

For romantic love and companionate love factors, the results showed that participants rated the husband who does not beat his wife, in both conditions ("jealousy" and "no jealousy") as being more loving, suggesting that the participants disapproved aggression irrespective of the context.

In contrast, Puente and Cohen (2003) found that in the case of "jealousy", the aggressive husband was seen as slightly more romantically loving (4.36/ aggression and 4.22/non-aggression). In our reproduction of the study, the non-aggressive husband was seen as more romantically loving (2.90/ aggression and 3.59/non-aggression). A similar difference was also found for the love companionate factor, in which the means for the aggressive (3.43) and non-aggressive husband (3.62) in case of "jealousy" were similar to the US study, while in the present study they were accentuated (2.36/ aggression and 3.44/non-aggression).

The data were also different from those found by Vandello and Cohen (2003) who, when comparing a sample consisting of Americans and Brazilians, they found that only the Americans believed that the man who assaulted his wife loved her less than one who simply yelled at her.

Violence against women is influenced by culture, particularly because it is related to social rules of gender and family, so this phenomenon can only be understood within the cultural context in which it occurs (Gomes, Diniz, Araújo, \& Coelho, 2007; Vandello \& Cohen, 2003). Therefore, because it is a survey conducted in different cultures (Brazil and United States), it is natural to find differences between the data. Moreover, individuals are constantly interacting with cultural practices and products, which can determine a great variability within the same culture.

For the prognostic factor, as in the results of Puente and Cohen (2003), the present study found little difference, with a trend to a worse prognosis in the "jealousy" condition, especially for the aggressive husband (2.08). This finding is in agreement with the study of Zordan, Wagner, and Mosmann (2012) who investigated the alleged reasons for separation by analyzing documents of 152 marital separations filed between 1992 and 2006. Among the reasons stated (only $20.4 \%$ of cases), the majority of couples stated fights and frequent arguments (28.9\%) and aggression of the spouse $(23.7 \%)$ as being the reason for separation.

For the understanding and morally bad factors, non-aggression was seen as more understandable in the case of "jealousy" (6.09 in the original study and 3.07 in the present study) and the husband was considered more morally wrong when he presented an aggressive behavior in the case of "no jealousy" (2.90 in the original study and 4.00 in the present study), results that corroborate those found by Puente and Cohen (2003).

It is noteworthy that for all the factors, aggression in the case of "no jealousy" had a sharply negative meaning both in the US study and in the present one, which is not observed in the case of "jealousy" in which the meaning of aggression seems to be minimized.

For example, when comparing situations in which there was aggression, the participants 
pointed out that the husband was more loving if the assaulted his wife in the case of "jealousy" (2.90/romantic love and 2.36/companionate love) than when he assaulted the wife in the case of "no jealousy" (2.11/romantic love and 1.81/companionate love).

It may concluded that although participants negatively evaluate violence against women when explicitly asked, a more refined analysis of the results suggests that the meaning of aggression is minimized when this occurs in a context of "jealousy". In the study of Puente and Cohen (2003), significant values were found between "jealousy" and aggression for all five factors: romantic love, companionate love, prognosis, understanding and morally bad.

In our study, the statistically significant $F$ values were restricted to four factors: romantic love $F$ (1.262): 23.18, $p<0.001$ (Jealousy); $F(1.262$ ): $7.00, p<0.01$ (No jealousy), companionate love $F$ (1.262): 4.81, $p<0.03$ (Jealousy); Prognosis $F$ (1.262): $6.11 p<0.015$ (Jealousy); and understanding $F(1.262): 37.39, p<0.001$ (Jealousy) and $F(1.262$ ): $36.81, p<0.001$ (No jealousy).

These data point to a difference between the situations of aggression and non-aggression, involving "jealousy", in four of the five factors (romantic love, companionate love, prognosis and understanding) and "no jealousy" in two factors (romantic love and understanding). Together, the data can be an indicator that it would be more justifiable if the husband beat his wife in the case of "jealousy". Thus, at least in part, the meaning of aggression in the case of jealousy is minimized, a result that is in agreement with the original study and with the study of Vandello and Cohen (2003). According to the latter, in some cultures of honor it is tolerable that the husband "washes his honor with blood", so aggression in the case of "jealousy" becomes less stigmatized and, in some cases, even acceptable.

Historically, in Brazil, crime against women has been often accepted on the grounds of adultery (Blay, 2003). After the feminist movements, the thesis of "legitimate defense of honor" was minimized. Currently, the crime of passion can be considered manslaughter with malice (mitigating factors) or a felony (no mitigating factors), but the base reasons is estimated on the basis of what is accepted or not by society, average morality (Toigo, 2010). Thus, one can assume that the thesis of "defense of the male honor" still prevails in our culture, as indicated by the data from the survey, affecting the way crimes against women are judged.

The Multivariate Analysis of Variance (Manova) among the dependent variables (factors) and the independent (situations of aggression and non-aggression) resulted in the following Wilks' Lambda values $(\lambda)$ : $F(5.258) 58.445, p<0.001$ for "jealousy" and $F(5.258) 94.577, p<0.001$ for "no jealousy", indicating that there was a significant difference in the answers given by the participants when they evaluated the situations of aggression and non-aggression. Regarding gender, we could not identify any significant differences between "jealousy" and "no jealousy", whose $t$ values, in most cases, were low. This indicates that responses of men and women are similar when they answer about emotional jealous behavior.

Similarly, Costa and Barros (2008) and Gomes and Costa (2014) also found strong correlations for the gender variable. Costa and Barros (2008) tested the hypothesis defended in evolutionary studies that state that men and women differ as to situations that trigger "jealousy"; thus, men would be jealous in situations involving sexual infidelity, while women would be if faced with love infidelity. The results showed that gender was not a relevant issue to determine the aspects that each person values in a love relationship and, above all, with respect to situations that trigger "jealousy".

When investigating the degree of agreement of 252 participants with common descriptive rules in a Western society that relate to violence against women, Gomes and Costa (2014) also found no significant correlations for the gender variable. However, the results indicated a strong correlation to the level of education, that is, the lower the level of education; the higher was the compliance with the rules related to violence against women. This may also have been a significant variable for the data found in the present study, in which the sample 
was composed of Humanities college students. Based on the data of our study and the literature, it can be inferred that violence against women is a cultural practice in our country and social rules regarding male honor, female submission and "jealousy" influence this practice.

Despite the numerous contributions, Puente and Cohen (2003) point out some limitations regarding the research conducted, suggesting additional studies to further knowledge in this field. Among their suggestions, the authors propose studies involving a large number of qualitatively different situations that describe other contexts of jealousy and no jealousy; using a sample with different characteristics from the one used; and investigating love as a justification factor for violence, beyond correlational analyses. Other suggestions and limitations mentioned by authors can be found in the article by Puente and Cohen (2003).

The limitations not mentioned by the original study, but were found in this replication can be highlighted the difficulty reported by the participants in completing the questionnaire having access only to the information provided in audio recordings. Often the participants expressed that because they lack access to information on the history and current conditions of both the husband, the marriage did not feel able to answer some items, such as: how her husband was a bad parent or as he was evil. This difficulty may have influenced in completing the questionnaire and therefore the results found in the research.

Another limitation is the sample used in our study. The sample consisted of college students from the Human Sciences Department with ages between 18 and 35 years. We can note that this is a specific population, in which variables such as age, education and the field of study may have influenced the results. Thus, further studies could be carried out including different age groups, different levels of education and/or comparing samples from different field of study, such as Exact, Social and Biological Sciences.

In addition, as our study was conducted in 532 a capital city and the sample largely consisted of individuals from a specific region in the country, the Northeast, this could have influenced the results. The data found in the violence map, for example, show that, particularly in the case of femicide, the rates vary according to region and they are higher in capital cities (Waiselfisz, 2012, 2014).

Finally, the literature has shown that there are some limitations in terms of methodology in studies that perform cross-cultural comparisons. According to Heine, Lehman, Peng, and Greenholtz (2002), there may be cultural differences that influence the participants when filling out a Likert scale, for example. Some of the differences mentioned by the authors are as follows: members of some cultures may have a higher probability of choosing the options placed in the middle of the scale, options such as "moderate"; some translation errors can produce measures with different meanings in different cultures; members of different cultures may find it easier to fill out the scale, while other may find it more difficult; and finally, members in some cultures may be more likely to conceal their answers in the questionnaire than others.

In spite of these limitations, the study has contributed to the understanding of the relationship between "jealousy", love (even if implicitly) and violence in the population studied, making it relevant to conduct further research to improve theoretical and practical knowledge.

\section{Contributors}

\section{ALMEIDA, L. GONDIM, M. SILVA, T. ALMEIDA} e $V$. LIMA participated in the research project development, the experimental strategy, data collection, tabulation, discussion of the results and elaboration of the article. R. S. CAMPOS and S. M. SILVA participated in data collection, tabulation, discussion of the results and elaboration of the article. H. GOMES, N. COSTA and R. S PINHEIRO participated in the development of experimental strategy, tabulation, discussion of results, preparation of the article and the research project.

\section{References}

Baptista, A. C. C. C. (2012). Estudo de caso de uma mulher sujeita a violência conjugal psicológica, com 
crenças de amor romântico e uma história de violência interparental (Dissertação de mestrado não-publicada). Instituto Universitário Ciências Psicológicas, Sociais e da Vida, Lisboa, Portugal.

Blay, E. A. (2003). Violência contra a mulher e políticas públicas. Estudos Avançados, 17(49), 87-98. http:// dx.doi.org/10.1590/S0103-40142003000300006

Costa, M. N. P. (2009). Busca de definição operacional de ciúme: uma construção teórica e empírica (Tese de doutorado não-publicada). Universidade Federal do Pará, Belém.

Costa, N., \& Barros, R. S. B. (2008). Celos: test de definición y una hipótesis sobre la diferencia de género bajo la óptica del análisis de la conducta. Terapia Psicológica, 26(1), 15-25. http://dx.doi.org/10.4067/S0718-480 82008000100002

Gomes, H. C. R., \& Costa, N. (2014). Violência contra a mulher: uma pesquisa empírica sobre regras descritivas comuns na sociedade ocidental. Acta Comportamentalia, 22(1), 89-100.

Gomes, N. P., Diniz, N. M. F., Araújo, A. J. S., \& Coelho, T. M. F. (2007). Compreendendo a violência doméstica a partir das categorias gênero e geração. Acta Paulista de Enfermagem, 20(4), 504-508. http://dx.doi.org/ 10.1590/S0103-21002007000400020

Heine, S. J., Lehman, D. R., Peng, K., \& Greenholtz, J. (2002). What's wrong with cross-cultural comparisons of subjective likert scales?: The reference-group effect. Journal of Personality and Social Psychology, 82(6), 903-918. http://dx.doi.org/10.1037/0022-3514.8 2.6.903

Lacerda, L., \& Costa, N. (2013). Relação entre comportamentos emocionais ciumentos e violência contra a mulher. Revista Brasileira de Terapia Comportamental e Cognitiva, 15(3), 21-36.

Puente, S., \& Cohen, D. (2003). Jealousy and meaning (or nomeaning) of violence. Personality and Social Psychology Bulletin, 29(4), 449-460. http://dx.doi.org/ 10.1177/0146167202250912

Schraiber, L. B., D'Oliveira, A. F. P. L., França-Junior, I., Diniz, S., Portella, A. P., Ludemir, A. B., ... Couto, M. T. (2007). Prevalência da violência contra a mulher por parceiro íntimo em regiões do Brasil. Revista de Saúde Pública, 41(5), 797-807. http://dx.doi.org/10.1590/s0 034-89102007000500014

Sinclair, L. C. A. (2010). Introdução à violência contra a mulher. In L. C. A. Williams, J. M. D. Maia, \& K. S. A. Rios (Orgs.), Aspectos psicológicos da violência: pesquisa e intervenção cognitivo-comportamental (pp.69-82). Santo André: ESETec. (Trabalho originalmente publicado em 1985).

Skinner, B. F. (1995). O perceber. In B. F. Skinner. Sobre o Behaviorismo (pp.65-77). São Paulo: Cultrix. (Trabalho originalmente publicado em 1974).

Toigo, D. M. (2010). Breve análise das teses defensivas da legítima defesa da honra e da privilegiadora da violenta emoção no tribunal do júri em homicídios passionais praticados por homens contra mulheres. Unoesc \& Ciência - ACSA, 1(1), 13-20.

Waiselfisz, J. J. (2012). Mapa da violência 2012: atualização: homicídio de mulheres no Brasil. Rio de Janeiro: Cebela/Flacso. Recuperado em novembro 28, 2014, de http://www.mapadaviolencia.org.br/ pdf2012/MapaViolencia2012_atual_mulheres.pdf

Waiselfisz, J. J. (2014). Mapa da violência 2014: homicídios e juventude no Brasil. Brasília: SecretariaGeral da Presidência da República. Recuperado em novembro, 28, 2014, de http://www.mapada violencia.org.br/pdf2014/Mapa2014_Atualizacao Homicidios.pdf

Vandello, J. A., \& Cohen, D. (2003). Male honor and female fidelity: Implicit cultural scripts that perpetuate domestic violence. Journal of Personality and Social Psychology, 84(5), 997-1010. http://dx.doi.org/ 10.1037/0022-3514.84.5.997

Zordan, E. P., Wagner, A., \& Mosmann, C. (2012). O perfil de casais que vivenciam divórcios consensuais e litigiosos: uma análise das demandas judiciais. Psico-USF, 17(2), 185-194. http://dx.doi.org/10.1590/S1413-82 712012000200002

Received: May 20, 2014

Final version: December 15, 2014

Approved: March 24, 2015 
